\title{
Mode choice model for public transport (ferry, fast ship and aircraft) study case: Kupang - Rote Route
}

\author{
Margareth E. Bolla ${ }^{1, *}$, Rossy A. Bella ${ }^{2}$, Aprianto Nomleni ${ }^{3}$, and Desy Yuliaty Tungga ${ }^{2}$ \\ ${ }^{1}$ Doctoral Study Program of Civil Engineering, Faculty of Engineering, Brawijaya University, Malang, Indonesia \\ ${ }^{2}$ Civil Engineering Department, Faculty of Science and Engineering, Nusa Cendana University, Kupang, Indonesia \\ ${ }^{3}$ Magister Study Program of Water Resources Engineering, Faculty of Engineering, Brawijaya University, Malang, Indonesia
}

\begin{abstract}
The mode of transportation that travels from Kupang City to Rote Ndao Regency is currently a mode of sea transportation and air transportation. This study aims to find out user information based on its mode choices and model it in the multinomial log function, besides that it's hoped that this result can be used as a reference in determining policies that improve functions and facilities for mobilizing people, goods and services carried out on the Kupang to Rote.Data analysis was carried out in two ways, namely with descriptive statistical analysis techniques to explain the characteristics of respondents and multinomial logistic regression analysis to create a model of mode transportation selection for Kupang-Rote service. The results of the study showed that users of transportation services from Kupang to Rote, generally men prefer to use ferry boats while women prefer to use fast boats. The characteristics of respondents is age 20-39 years. While the factors that influence the choice of transportation are the influence of luggage, weather and comfort. For the selection model, the probability of a speedboat is $34.65 \%$,the probability of choosing a ferry is $42.96 \%$, and the probability of choosing an aircraft is $22.3 \%$.
\end{abstract}

\section{Introduction}

East Nusa Tenggara Province (NTT) has 427 islands, including Rote Island. Formerly Rote was included in Kupang Regency, but since 2002 it has been established as Rote Ndao District. Rote Ndao itself is Indonesia's southernmost island which borders Australia. Geographical conditions between Rote Ndao District and Kupang City which are separated by the sea cause traffic movement to fulfill the needs of goods and services between islands. The mode of transportation that travels from Kupang City to Rote Ndao Regency is currently a mode of sea transportation and air transportation, whether by plane, ferry boat or fast ship. The main sea ports in Rote Ndao Regency are Baru Beach and Baa. Consideration of transportation selection certainly depends on factors that can affect service user satisfaction. The factors used in the study include income, age, gender, purpose of travel, terminal waiting time, travel time, travel costs, and service level. From the results of his research, the factors that have a significant influence in making modal choices are departure time, travel costs and also reasons for traveling[1]. By adopting the above significant factors accompanied by the addition of several other factors such as distance traveled, luggage and weather influences, then the modeling of transportation mode selection between ferries, speedboats and aircraft serving Kupang departure route to Rote analysis is carried out. This study aims to find out user information based on the choice of mode and model it in multinomial $\log$ functions, where to find out the characteristics of the users of the transportation mode for the Kupang - Rote route and find out the factors that influence the choice of transportation modes between ferries, fast boats and planes in the Kupang - Rote route, besides that this result can be used as a reference in determining policies that improve functions and facilities to mobilize people, goods and services carried out on the Kupang to Rote route.

\section{Model of mode selection}

\subsection{Model definition}

In the transportation planning process, one step that must be done is analyzing each relevant data and information as a basis for predicting what will happen in the future. This data and information can be secondary data that obtained from related agencies, or as primary data can be obtained from direct observation on location of research or in reality[4].Primary data obtained from direct observing activities is difficult to analyze and cannot be used as a basis for predictions of incident and results in the future [4]. For necessity of estimation of these results,

\footnotetext{
Corresponding author: margaretachristami@gmail.com
} 
this realistic data and information needs to be simplified as optimally as possible, without deviating from the intent, purpose, and substance of the relevant data and information.Summarize and simplify the realistic conditions activities are known as modeling activities. Thus, the model can be defined as follows [4]:

$>$ The model is a concise representation of the real conditions and tangible forms of design that can explain or represent the real conditions for a particular purpose [2].

$>$ Model is a representation or formalization in certain agreed languages upon from a particular condition [6].

$>$ Model is a main framework or formalization of information / data about collected real conditions to study / analyze the real system [3].

Therefore, the model is a tool that can be used to represent and simplify a reality. The simplification of reality aims to provide a deeper explanation and for the purposes of forecasting.

\subsection{Utilities}

Value of travel satisfaction in using alternative modes of transportation, influenced and related to variables that are considered to have a strong relationship with the behavior of the traveler and the form of the relationship can be seen through the utility functions are as follows[4]:

$\mathrm{U}=\mathrm{f}(\mathrm{V} 1, \mathrm{~V} 2, \mathrm{~V} 3, \ldots, \mathrm{Vn})$

Where :

$\mathrm{U}=$ The value of the traveler's utility using transportation modes

$\mathrm{V} 1$ to $\mathrm{Vn}=$ Variables that are considered to influence the value of satisfaction using certain modes of transportation

$\mathrm{F}=$ Mathematical functional relationship

The activity of determining and observing the behavior of the traveler through the utility function can be done with two approaches. The approach that used determines the probability choice model. Both approaches are:

\subsubsection{Aggregate approach}

The aggregate approach is an approach that analyzes the behavior of the traveler as a whole. The aggregate approach can be done in two ways, namely [4]:

$>$ Divide the object of observation on several groups that have the characteristics of relatively homogeneous elements (the same).

$>$ Aggregate the disaggregate data, which functions for a particular group can be derived from individual utility functions as members of the group.

\subsubsection{Disaggregate approach}

The disaggregate approach is an approach that analyzes the behavior of individual travelers. This includes how to formulate individual behavior into the model of transportation needs. The disaggregate approach can be done in two ways, namely [4]:

a. Deterministic Disaggregate
This approach is carried out if the traveler is able to identify all available alternative modes and use all information to make decisions. The form of the model is a model of multiple linear equations without elements of errors as follows:

$\mathrm{Ui}=\mathrm{a}+\mathrm{b}_{1} \mathrm{~T}+\mathrm{b}_{2} \mathrm{X}+\mathrm{b}_{3} \mathrm{C}$

Where:

Ui = satisfaction value using i mode

$\mathrm{T}=$ time variable on the vehicle

$\mathrm{X}=$ time variable outside the vehicle

$\mathrm{C}=$ variable transportation costs

a $=$ constant

b1 to $b 3=$ parameter of satisfaction function for each variable (regression coefficient).

\section{b. Stochastic Disaggregate}

In this approach, the value of satisfaction is more realistic because it considers the unobservable elements that occur in the reality. All unobservable elements that occur in the reality, in this approach is represented by an element of error (random) that is random or stochastic, so the model becomes:

$\mathrm{U}_{\mathrm{m}}=\beta_{0}+\beta_{1 \mathrm{tm}}+\beta_{2 \mathrm{xm}}+\beta_{3 \mathrm{~cm}}+$ en

Where:

$\mathrm{Um} \quad=$ value of satisfaction function using $m$ mode tm-cm $=$ value of satisfaction function using $m$ mode $\beta 1-\beta 3=$ value of satisfaction function using $m$ mode

en $=$ error factor or stochastic element, that is a random variable that follows a certain distribution form

$\beta 0=$ characteristic constants of alternative satisfaction values, if all variables $t m$ to $v m$ are zero. Forecasting is said to be relatively precise, if the en value is at least close to zero (to a minimum) or $e n=0$

\subsection{Multinomial logit model (MNL)\%}

This model is the most famous and popular discrete choice model. Multinomial logistic regression is a logistic regression where the dependent variable currently has a scale that is polycotomic or multinomial. Thus, this model was chosen because there are more modes for private vehicles, microbus, taxi, motorcycle, etc.Multinomial regression is a form of a model with a relationship function logit where the response is in the form of Nominal qualitative data with more than two categories. The characteristics are carried out between categories of responses are unordered, meaning that between categories there is no level and the nature. Beside that Multinomial regression is more specific to models more than 2 compare with standard method that only calculates the equation model with the Logit form link function where the response is in the form of nominal quality data with the number of categories equal to two or below. Regression models with variables that are nominally sourced are different from the categories of codes 1,2 and 3. The existing $Y$ variables are parameterized into three functions. The logistic model is a logarithm of opportunities that occur in forms of models described through algorithms [4]: 


$$
\mathrm{P}(\mathrm{i})=\frac{e^{U i}}{e^{U i}+\sum_{\varepsilon} U_{j n}}
$$

Where :

P (i) = Opportunity imode to be selected

$\mathrm{Ui} \quad=$ Value of the benefits of using $i$ mode

Ujn $=$ Total benefits value of other modes besides $i$ mode. (Moda j1, .... jn)

e $\quad=$ Exponent

\subsection{Sample determination}

To determine the amount of samples from a population, can used the Slovin formula is as follows [7]:

$$
\mathrm{n}=\frac{N}{1+N \cdot d^{2}}
$$

Where :

$\mathrm{n}=$ number of samples

$\mathrm{N}=$ number of population

$\mathrm{d}=$ percent error rate $(d$ value $=10 \%)$

\subsection{Population and sample}

\subsubsection{Population}

Population is an area of generalization consisting of objects / subjects that have certain qualities and characteristics determined by researchers to be studied and then drawn conclusions [5]. The population in this study consisted of two populations that were distinguished based on the location of the study, namely the population of transportation service users from Kupang to Rote. Population data for users of transportation services both from Kupang is shown in Table 1 and Table 2.

Table 1. Recapitulation of fast ship and ferry ships in 2016

\begin{tabular}{|c|c|c|c|}
\hline \multirow{2}{*}{ No. } & \multirow{2}{*}{ Month } & $\begin{array}{c}\text { Total passenger } \\
\text { Fast Ship (Person) }\end{array}$ & $\begin{array}{c}\text { Total passenger } \\
\text { Ferry (Person) }\end{array}$ \\
\cline { 3 - 4 } & Kupang-Rote & Kupang-Rote \\
\hline 2 & January & 1957 & 8862 \\
\hline 3 & March & 3488 & 8518 \\
\hline 4 & April & 4130 & 12953 \\
\hline 5 & May & 3925 & 30585 \\
\hline 6 & June & 5162 & 34026 \\
\hline 7 & July & 3923 & 43057 \\
\hline 8 & August & 4507 & 36367 \\
\hline 9 & September & 5598 & 33314 \\
\hline 10 & October & 5201 & 32633 \\
\hline 11 & November & 4884 & 28867 \\
\hline
\end{tabular}

\begin{tabular}{|c|c|c|c|}
\hline \multirow{2}{*}{ No. } & \multirow{2}{*}{ Month } & $\begin{array}{c}\text { Total passenger } \\
\text { Fast Ship (Person) }\end{array}$ & $\begin{array}{c}\text { Total passenger } \\
\text { Ferry (Person) }\end{array}$ \\
\cline { 3 - 4 } & & Kupang-Rote & Kupang-Rote \\
\hline 12 & December & 2488 & 31780 \\
\hline \multicolumn{2}{|c|}{ Total } & 47359 & 46301 \\
\hline
\end{tabular}

Source: Bahari express 2016 passenger data and production data of PT. Kupang ASDP in 2016

Table 2. Aircraft passenger recapitulation in 2016

\begin{tabular}{|c|c|c|}
\hline No & Rute & Jumlah Penumpang (Org) \\
\hline 1 & Kupang-Rote & 21277 \\
\hline
\end{tabular}

Source: UPBU D.C Air transport traffic data. Saudale-rote

Based on the data of passenger recapitulation for each mode of transportation both from Kupang and from Rote, the population can be calculated for 1 area of the research location as follows:

Population Kupang $=$ JP fast ship + JP plane + JP ferry boat

Description:

jp = number of passengers

So, the following results are obtained:

Populasi_kupang $=47,359$ people $+21,277$ people + 320,664 people

Populasi_kupang $=389,300$ people

\subsubsection{Sample}

Sample is a part of the amount and characteristics owned by the population [4]. Based on existing population data, the sample calculation is carried out as followsequation 5 . In each study area there are 3 points of the research location, in Kupang consists of Tenau Harbor, Bolok Port and Eltari Airport while in Rote it consists of Ba'a Port, New Beach Harbor and D.C Saudale Airport. Then, the amount of respondents for each study area was divided into 3 parts. One hundred respondents from Kupang were divided into 3 locations, each location received 33.33 or equal to 34 respondents. However, in this study 35 respondents were selected for each research location, likewise withRote area the questionnaire distributed for each location in Rote was 35 questionnaires. So that the questionnaires distributed to respondents in Kupang and in Rote amounted to 150 questionnaires (can be seen in Table 3)

Table 3. Amount of Research Samples

\begin{tabular}{|l|l|l|l|l|}
\hline \multirow{2}{*}{ Location } & $\begin{array}{c}\text { No } \\
\cdot\end{array}$ & Moda & $\begin{array}{c}\text { Amount } \\
\text { of Sample }\end{array}$ & $\begin{array}{c}\text { Total } \\
\text { of } \\
\text { Sample }\end{array}$ \\
\hline \multirow{2}{*}{ Kupang } & 1 & Fast Ship & 35 & \\
\cline { 2 - 4 } & 2 & Aircraft & 35 & \multirow{2}{*}{$\begin{array}{l}105 \\
\text { sample }\end{array}$} \\
\cline { 2 - 4 } & 3 & Ferry & 35 & \\
\hline
\end{tabular}




\section{Data collection techniques}

Primary data is obtained from the results of questionnaire surveys in the field. Distribution of questionnaires was given to respondents who were ferry service users, speed boats and aircraft. The questionnaire survey was conducted at the port and airport waiting room. For aircraft departing from Kupang the questionnaire survey was carried out in the waiting room of Eltari International Airport. Ferry boats were also carried out in the waiting room and also in ships at Bolok Port (which departs from Kupang).Meanwhile, a survey of fast boat service users was carried out in the waiting room and in ships in Tenau Port (passengers from Kupang to Rote). The form of the survey form questions includes two things. First, questions are made to determine the characteristics of the users of transportation services and the characteristics of the transportation system of the three modes of transportation. Second, questions are made to find out the respondents' preferences towards alternative modes of transportation selection with several types of changes in conditions offered.

\subsection{Primary data}

Primary data is data that can be used directly from the original source. The primary data in this study were sourced from the results of a survey of needs for ferry passengers, speedboats and planes from Kupang and from Rote. The data that will be obtained from the survey results in each access mode are as follows:

$>$ Characteristics of Respondents

The characteristics of the data collected are as follows age, work, travel purpose, reasons for choosing transportation,travel frequency, monthly income, distance and travel time from the place of origin to the airport or port, distance and travel time from the airport or port to the destination and estimated total transportation costs in traveling

$>$ Service user preferences for service attributes collected are as follows Cost (X1), Travel time (X2), Luggage (X3), Weather (X4) and Comfort (X5)

\subsection{Secondary data}

Secondary data is data obtained from relevant agencies, in this case from PT. ASDP (River Lake and Crossing Transportation) Kupang Branch and Rote Supervision, Bahari Express Private Ship Company, PT. Angkasa Pura I, UPBU DC. Saudale Rote and literature studies that discuss research topics. The data obtained includes data on fleet numbers, type of fleet, number of passengers per day, tariffs and frequency of services, ferry boats and fast boats that serve Kupang - Rote.

\section{Data analysis techniques}

Survey data that has been collected is then processed so it can be used as input data in the analysis process using the IBM SPSS version 23 application program. Data analysis is done in two ways, namely descriptive statistical analysis techniques to explain the characteristics of respondents and multinomial logistic regression analysis for make a model of choosing the transportation modes for Kupang-Rote service route.

After the equation model is obtained, the statistics are tested to find out whether the mode selection equation is feasible to use. Then do the probability calculation of each mode selection for Kupang to Rote route and the opposite route. The probability calculation of each mode is in accordance with equation $6,8,10$ which in this study was carried out on ferries, fast ships and aircraft. The modal choice probability calculation formula is as follows:

$$
\begin{aligned}
& \mathrm{P}(\text { ferry })=\frac{e^{\text {Ufast ship }}}{e^{\text {Uferry }}+e^{\text {Ufast ship }}+e^{\text {Uaircraft }}} \\
& \text { Ukapal feri }=(\beta 1 . \mathrm{X} 1)+(\beta 2 . \mathrm{X} 2) \ldots \ldots .+(\beta \mathrm{n} . \mathrm{Xn}) \\
& \mathrm{P}(\text { fast ship })=\frac{e^{\text {Ufast ship }}}{e^{\text {Uferry }}+e^{\text {Ufast ship }}+e^{\text {Uaircraft }}} \\
& \mathrm{U} \text { fast ship }=(\beta 1 . \mathrm{X} 1)+(\beta 2 . \mathrm{X} 2) \ldots \ldots+(\beta \mathrm{n} . \mathrm{Xn})
\end{aligned}
$$

\subsection{Multinomial logistic regression analysis}

Multinomial Logit Analysis of Kupang-Rote Service Routes. The utility function equation between fast boats, ferries and aircrafts is affected by five factors such as costs, travel time, luggage, weather and comfort. The general form of the model is in accordance with equation (2.2) as described in chapter two points 2.4.2. So in this study the form of utility equationsfrom Kupang to Rote service route are as follows:

$\mathrm{Y}=\mathrm{a}+\mathrm{b} 1 \mathrm{X} 1+\mathrm{b} 2 \mathrm{X} 2+\mathrm{b} 3 \mathrm{X} 3+\mathrm{b} 4 \mathrm{X} 4+\mathrm{b} 5 \mathrm{X} 5$

Where:

$\mathrm{Y}=$ Utility of fast ships, ferries and aircrafts

$\mathrm{X}_{1}=$ Cost effect

$\mathrm{X}_{2}=$ Effect of travel time

$\mathrm{X}_{3}=$ Influence of luggage

$\mathrm{X}_{4}=$ Effect of weather

$\mathrm{X}_{5}=$ Effect of comfort

Then made several alternative equations which are formed from the five independent variables to choose the best model equation. The best model equation criteria are illustrated by the value of $\mathrm{R}^{2} \mathrm{Mc}$. Fadden. The greater the value of $\mathrm{R}^{2}$ Mc. Fadden, the better the regression model equation is. Equations alternative that are formed along with the value of $\mathrm{R}^{2} \mathrm{Mc}$. Fadden can be seen in Table 4 below: 
Table 4. Equations Alternative That Are Formed Along With The Value Of R2 Mc. Fadden

\begin{tabular}{|c|c|c|c|}
\hline No. & Alternative & Form of Equations & $\begin{array}{l}\mathrm{R}^{2} \mathrm{Mc} \text {. } \\
\text { Fadden }\end{array}$ \\
\hline 1 & Alternative 1 & $y=a+b_{1} x_{1}$ & 0,731 \\
\hline 2 & Alternative 2 & $y=a+b_{2} x_{2}$ & 0,314 \\
\hline 3 & Alternative 3 & $y=a+b_{3} x_{3}$ & 0,513 \\
\hline 4 & Alternative 4 & $y=a+b_{4} x_{4}$ & 0,070 \\
\hline 5 & Alternative 5 & $y=a+b_{5} x_{5}$ & 0,059 \\
\hline 6 & Alternative 6 & $\mathrm{y}=\mathrm{a}+\mathrm{b}_{1} \mathrm{x}_{1}+\mathrm{b}_{2} \mathrm{x}_{2}$ & 0,782 \\
\hline 7 & Alternative 7 & $y=a+b_{1} x_{1}+b_{3} x_{3}$ & 0,851 \\
\hline 8 & Alternative 8 & $y=a+b_{1} x_{1}+b_{4} x_{4}$ & 0,765 \\
\hline 9 & Alternative 9 & $\mathrm{y}=\mathrm{a}+\mathrm{b}_{1} \mathrm{x}_{1}+\mathrm{b}_{5} \mathrm{x}_{5}$ & 0,758 \\
\hline 10 & Alternative 10 & $\mathrm{y}=\mathrm{a}+\mathrm{b}_{2} \mathrm{x}_{2}+\mathrm{b}_{3} \mathrm{x}_{3}$ & 0,660 \\
\hline 11 & Alternative 11 & $y=a+b_{2} x_{2}+b_{4} x_{4}$ & 0,382 \\
\hline 12 & Alternative 12 & $\mathrm{y}=\mathrm{a}+\mathrm{b}_{2} \mathrm{x}_{2}+\mathrm{b}_{5} \mathrm{x}_{5}$ & 0,327 \\
\hline 13 & Alternative 13 & $\mathrm{y}=\mathrm{a}+\mathrm{b}_{3} \mathrm{x}_{3}+\mathrm{b}_{4} \mathrm{x}_{4}$ & 0,537 \\
\hline 14 & Alternative 14 & $\mathrm{y}=\mathrm{a}+\mathrm{b}_{3} \mathrm{x}_{3}+\mathrm{b}_{5} \mathrm{x}_{5}$ & 0,527 \\
\hline 15 & Alternative 15 & $\mathrm{y}=\mathrm{a}+\mathrm{b}_{4} \mathrm{x}_{4}+\mathrm{b}_{5} \mathrm{x}_{5}$ & 0,128 \\
\hline 16 & Alternative 16 & $\mathrm{y}=\mathrm{a}+\mathrm{b}_{1} \mathrm{x}_{1}+\mathrm{b}_{2} \mathrm{x}_{2}+\mathrm{b}_{3} \mathrm{x}_{3}$ & 0,940 \\
\hline 17 & Alternative 17 & $\mathrm{y}=\mathrm{a}+\mathrm{b}_{1} \mathrm{x}_{1}+\mathrm{b}_{2} \mathrm{x}_{2}+\mathrm{b}_{4} \mathrm{x}_{4}$ & 0,833 \\
\hline 18 & Alternative 18 & $\mathrm{y}=\mathrm{a}+\mathrm{b}_{1} \mathrm{x}_{1}+\mathrm{b}_{2} \mathrm{x}_{2}+\mathrm{b}_{5} \mathrm{x}_{5}$ & 0,810 \\
\hline 19 & Alternative 19 & $\mathrm{y}=\mathrm{a}+\mathrm{b}_{1} \mathrm{x}_{1}+\mathrm{b}_{3} \mathrm{x}_{3}+\mathrm{b}_{4} \mathrm{x}_{4}$ & 0,860 \\
\hline 20 & Alternative 20 & $\mathrm{y}=\mathrm{a}+\mathrm{b}_{1} \mathrm{x}_{1}+\mathrm{b}_{3} \mathrm{x}_{3}+\mathrm{b}_{5} \mathrm{x}_{5}$ & 0,868 \\
\hline 21 & Alternative 21 & $\mathrm{y}=\mathrm{a}+\mathrm{b} 1 \mathrm{X} 1+\mathrm{b}_{4} \mathrm{x}_{4}+\mathrm{b}_{5} \mathrm{x}_{5}$ & 0,797 \\
\hline 22 & Alternative 22 & $\mathrm{y}=\mathrm{a}+\mathrm{b}_{2} \mathrm{x}_{2}+\mathrm{b}_{3} \mathrm{x}_{3}+\mathrm{b}_{4} \mathrm{x}_{4}$ & 0,722 \\
\hline 23 & Alternative 23 & $\mathrm{y}=\mathrm{a}+\mathrm{b}_{2} \mathrm{x}_{2}+\mathrm{b}_{3} \mathrm{x}_{3}+\mathrm{b}_{5} \mathrm{x}_{5}$ & 0,691 \\
\hline 24 & Alternative 24 & $\mathrm{y}=\mathrm{a}+\mathrm{b}_{3} \mathrm{x}_{3}+\mathrm{b}_{4} \mathrm{x}_{4}+\mathrm{b}_{5} \mathrm{x}_{5}$ & 0,555 \\
\hline 25 & Alternative 25 & $\begin{array}{l}\mathrm{y}=\mathrm{a}+\mathrm{b}_{1} \mathrm{x}_{1}+\mathrm{b}_{2} \mathrm{x}_{2}+\mathrm{b}_{3} \mathrm{x}_{3}+ \\
\mathrm{b}_{4} \mathrm{x}_{4}\end{array}$ & 0,946 \\
\hline 26 & Alternative 26 & $\begin{array}{l}\mathrm{y}=\mathrm{a}+\mathrm{b}_{1} \mathrm{x}_{1}+\mathrm{b}_{2} \mathrm{x}_{2}+\mathrm{b}_{3} \mathrm{x}_{3}+ \\
\mathrm{b}_{5} \mathrm{x}_{5}\end{array}$ & 0,941 \\
\hline 27 & Alternative 27 & $\begin{array}{l}\mathrm{y}=\mathrm{a}+\mathrm{b}_{1} \mathrm{x}_{1}+\mathrm{b}_{2} \mathrm{x}_{2}+\mathrm{b}_{4} \mathrm{x}_{4}+ \\
\mathrm{b}_{5} \mathrm{x}_{5}\end{array}$ & 0,891 \\
\hline 28 & Alternative 28 & $\begin{array}{l}y=a+b_{1} x_{1}+b_{3} x_{3}+b_{4} x_{4}+ \\
b_{5} x_{5}\end{array}$ & 0,929 \\
\hline 29 & Alternative 29 & $\begin{array}{l}y=a+b_{2} x_{2}+b_{3} x_{3}+b_{4} x_{4}+ \\
b_{5} x_{5}\end{array}$ & 0,726 \\
\hline 30 & Alternative 30 & $\begin{array}{l}y=a+b_{1} x_{1}+b_{2} x_{2}+b_{3} x_{3}+ \\
b_{4} x_{4}+b_{5} x_{5}\end{array}$ & 0,953 \\
\hline
\end{tabular}

Based on the Table 4 several equations alternativeare produced, which have the largest value of $\mathrm{R}^{2} \mathrm{Mc}$. Fadden is 0.953 as in the following equationn 12 :

$\mathrm{Y}=\mathrm{a}+\mathrm{b} 1 \mathrm{X} 1+\mathrm{b} 2 \mathrm{X} 2+\mathrm{b} 3 \mathrm{X} 3+\mathrm{b} 4 \mathrm{X} 4+\mathrm{b} 5 \mathrm{X} 5$

\subsection{Simultaneous test}

Based on the results of the analysis seen from Table 5, this test serves to determine the significant effect of independent variables on transportation mode selection decisions (dependent variable). The Examination Hypothesis is as follows:

- $\mathrm{H}_{0}$ means that the independent variable does not affect the dependent variable

- $\mathrm{H}_{1}$ means that at least one independent variable has a significant effect on the dependent variable
Table 5. Simultaneous test results

\begin{tabular}{|c|c|c|c|c|}
\hline \multirow{2}{*}{ Model } & $\begin{array}{l}\text { Model } \\
\text { Fitting } \\
\text { Criteria }\end{array}$ & \multicolumn{3}{|c|}{$\begin{array}{c}\text { Likelihood Ratio } \\
\text { Tests }\end{array}$} \\
\hline & $\begin{array}{c}-2 \text { Log } \\
\text { Likelihood }\end{array}$ & $\begin{array}{l}\text { Chi- } \\
\text { square }\end{array}$ & Df & Sig. \\
\hline $\begin{array}{c}\text { Intercept } \\
\text { Only }\end{array}$ & 218,577 & & & \\
\hline Final & 4,558 & 214,019 & 62 & 0,000 \\
\hline
\end{tabular}

H0 hypothesis is rejected if the chi-square probability value is greater than the chi-square table and if the $\mathrm{p}$-value $\leq \alpha$ is 0.05 . From the simultaneous test results in Table 5, it can be seen that the chi-square value is calculated at 214.019 while the chi-square table $(0.05 ; 62)$ is 81.3376 . This means that the chi-square count is greater than the chi-square table and also seen the $p$ value of $0.000<0.05$. Thus the $\mathrm{H}_{0}$ hypothesis is rejected and states that at least one independent variable has a significant effect on the dependent variable or in other words, the overall independent variable influences the choice of transportation mode selection.

\subsection{Partial test}

The Likelihood Ratio Tests table in this test shows the contribution or influence of each independent variable on the transportation mode selection model. From the partial test results, it can be seen that the probability value smaller than alpha $5 \%$ is the variable influence of luggage (0.012), the influence of weather (0.038) and the influence of comfort (0.011). Then the variable that contributes to the model is the luggage, weather and comfort variables while the cost and travel time variable does not contribute to the model because it is not significant ( $p>0.05$ ).

Table 6. Likelihood ratio tests

\begin{tabular}{|c|c|c|c|c|}
\hline \multirow{2}{*}{ Effect } & $\begin{array}{c}\text { Model } \\
\text { Fitting } \\
\text { Criteria }\end{array}$ & \multicolumn{3}{|c|}{ Likelihood Ratio Tests } \\
\cline { 2 - 5 } & $\begin{array}{c}\text {-2 Log } \\
\text { Likelihood } \\
\text { of Reduced } \\
\text { Model }\end{array}$ & $\begin{array}{c}\text { Chi- } \\
\text { square }\end{array}$ & Df & Sig. \\
\hline Intercept & 4,558 & 0,000 & 0 & \\
\hline Cost & 9,965 & 5,407 & 4 & 0,248 \\
\hline Travel time & 9,562 & 5,004 & 4 & 0,306 \\
\hline Luggage & 7,551 & 2,993 & 4 & 0,012 \\
\hline Weather & 7,192 & 2,634 & 6 & 0,038 \\
\hline Convenience & 6,055 & 1,498 & 4 & 0,011 \\
\hline
\end{tabular}

\subsection{Model feasibility test}

In Table 7 Goodness of Fit, provides information of the Model feasibility testing to state the difference between the frequency of observation with the frequency of expectations or in other words empirical data is suitable or not. It is expected that there is no difference between 
the empirical data or the frequency of observation with the model or frequency of expectations. The model is said to be feasible if it is significantly above 0.05 and the chisquare value in the Deviation test is smaller than the chisquare table. If $\mathrm{D} \leq \mathrm{X}$ table $(105,264)$, then $\mathrm{H}_{0}$ is accepted. If $\mathrm{D} \geq \mathrm{X}$ table $(105,264)$, then $\mathrm{H} 0$ is rejected.

Table 7. Goodness of fit

\begin{tabular}{|c|c|c|l|}
\hline & Chi-square & \multicolumn{1}{c|}{ Df } & \multicolumn{1}{l|}{ Sig. } \\
\hline Pearson & 65,164 & 88 & 0,142 \\
\hline Deviance & 68,323 & 88 & 0,091 \\
\hline
\end{tabular}

The results of Model feasibility test or Goodness of Fit can be seen in Table 7 From the table it is known that the value of $\mathrm{D}(68,323) \leq$ Xtable $(105,264)$, then $\mathrm{H} 0$ is accepted and the significance value is 0,091 above the alpha value of 0,05 . It can be concluded that the model matches the empirical data or the multinomial logit model is suitable for use because a ood model is a model that accepts the null hypothesis.

\subsection{Model equations of Kupang-rote selection mode}

The logit function generated based on Table 8 parameter estimation is as follows:

Logit 1

$\mathrm{U}($ fast ship-aircraft $)=0,437+0,054 \mathrm{X}_{1}-0,741 \mathrm{X}_{2}-1,951 \mathrm{X}_{3}$ $1,603 \mathrm{X}_{4}+2,197 \mathrm{X}_{5}$

Logit 2

$\mathrm{U}($ ferry-aircraft $)=0,652+0,129 \mathrm{X}_{1-}$

$1,079 \mathrm{X}_{2}+2,125 \mathrm{X}_{3}+0,575 \mathrm{X}_{4}-2,059 \mathrm{X}_{5}$

Table 8 Parameter estimates

\begin{tabular}{|c|c|c|c|c|c|}
\hline \multicolumn{2}{|c|}{ Transportation Mode } & B & Wald & Df & Sig. \\
\hline \multirow{6}{*}{$\begin{array}{l}\text { Fast } \\
\text { Ship }\end{array}$} & Intercept & 0,437 & 0,700 & 1 & 0,403 \\
\hline & Cost (X1) & 0,054 & 0,007 & 1 & 0,935 \\
\hline & $\begin{array}{l}\text { Travel Time } \\
\text { (X2) }\end{array}$ & $-0,741$ & 1,265 & 1 & 0,261 \\
\hline & Luggage (X3) & $-1,951$ & 6,117 & 1 & 0,013 \\
\hline & Weather (X4) & $-1,603$ & 4,680 & 1 & 0,031 \\
\hline & Comfort (X5) & 2,197 & 3,709 & 1 & 0,054 \\
\hline \multirow{6}{*}{ Ferry } & Intercept & 0,652 & 1,611 & 1 & 0,204 \\
\hline & Cost (X1) & 0,129 & 0,032 & 1 & 0,858 \\
\hline & $\begin{array}{l}\text { Travel Time } \\
\text { (X2) }\end{array}$ & $-1,079$ & 2,281 & 1 & 0,131 \\
\hline & Luggage (X3) & 2,125 & 6,806 & 1 & 0,009 \\
\hline & Weather (X4) & 0,575 & 0,578 & 1 & 0,447 \\
\hline & Comfort (X5) & $-2,059$ & 7,440 & 1 & 0,006 \\
\hline
\end{tabular}

Description: Reference category $=$ Airplane.

The variables that influence the model in logit function 1 and 2 are those that have a significance value of $\mathrm{p}<0.05$. In logit 1 function, the comparison between fast ships and aircraft shows that the variables that affect the modal selection model for the Kupang-Rote route are luggage variables and weather variables. Significant $\mathrm{p}$ value of each variable is $p$ of luggage variable $0.013<0.05$ and the weather variable significant $p$ value $0.031<0.05$. The luggage variable has a lower influence on the selection of fast boats compared to aircraft with a coefficient value of -1.951 and significant at $p(0.013)$ $<0.05$. The weather variable in the logit 1 function gives the effect of choosing a fast ship lower than the aircraft. Coefficient value of Weather variable -1.603 and significant at $p<0.05$, means that when the weather is inadequate for sea transportation to be used, respondents will tend to choose a plane.

In logit 2 function, the comparison between ferry and aircraft shows that the variables that affect the modal selection model for the Kupang-Rote route are luggage variables and convenience variables. The significant value of $\mathrm{p}$ of luggage variable is $0.009<0.05$ and significant $\mathrm{p}$ of the convenience variable is $0.006<0.05$. The luggage variable has a higher influence on the selection of ferry than the aircraft with a coefficient of 2.125 and a probability of $0.006(\mathrm{p}<0.05)$. The convenience variable gives the effect of choosing a ferry boat lower than the aircraft with a coefficient value of 2.059 and a probability of $0.006(\mathrm{p}<0.05)$. Based on logit 1 and 2 equation, the multinomial logistic regression model is obtained as follows:

Fast Ship

$\frac{\mathrm{e}^{0,437-1,951 \mathrm{X} 3-1,603 \mathrm{X} 4}}{1+\mathrm{e}^{0,437-1,951 \mathrm{X} 3-1,603 \mathrm{X} 4}+\mathrm{e}^{0,652+2,125 \mathrm{X} 3-2,059 \mathrm{X} 5}}$

$\quad=$
$\quad \mathrm{e}^{0,652+2,125 \times 3-2,059 \times 5}$

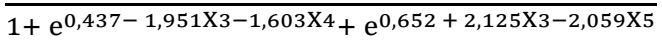

Aircraft

$\frac{1}{1+\mathrm{e}^{0,437-1,951 \mathrm{X} 3-1,603 \mathrm{X} 4}+\mathrm{e}^{0,652+2,125 \mathrm{X} 3-2,059 \mathrm{X} 5}}$

To find out the mode of transportation that has the greatest probability chosen by users of transportation services from Rote to Kupang, the estimated probability of response is used. The estimated probability of the response formed is as follows:

1. The probability of selecting a fast ship as a mode of transportation from Kupang to Rote:

Fast Ship =

$\frac{\mathrm{e}^{0,437-1,951 \times 3-1,603 \times 4}}{1+\mathrm{e}^{0,437-1,951 \times 3-1,603 \times 4}+\mathrm{e}^{0,652+2,125 \times 3-2,059 \times 5}}$
$=0,3465=34,65 \%$

2. The probability of selecting a ferry as a mode of transportation from Kupang to Rote:

$$
\begin{gathered}
\text { Ferry } \\
\frac{\mathrm{e}^{0,652+2,125 \times 3-2,059 \times 5}}{1+\mathrm{e}^{0,437-1,951 \times 3-1,603 \times 4}+\mathrm{e}^{0,652+2,125 \times 3-2,059 \times 5}} \\
=0,4296=42,96 \%
\end{gathered}
$$

3. The probability of selecting a aircraft as a mode of transportation from Kupang to Rote:

$$
\begin{aligned}
& \text { Aircraft } \\
& \frac{1}{\frac{1}{1+\mathrm{e}^{0,437-1,951 \mathrm{X} 3-1,603 \mathrm{X} 4}+\mathrm{e}^{0,652+2,125 \mathrm{X} 3-2,059 \times 5}}}=0
\end{aligned}
$$

Based on the calculation of the transportation modeprobability for the service route from Kupang to Rote, the results are obtained as above. Fast ship probability is $34.65 \%$, ferry probability is $42.96 \%$ and aircraft probability is $22.38 \%$. It is clearly known that of the three modes that have the largest probability of 
selecting transportation mode is the ferry with a percentage of probability $42.96 \%$.

\subsection{Discussion of ferry, fast ships and aircraft users characteristics (Kupang-rote routes)}

Based on the characteristics of ferry users analysis, fast ships and aircraft for both service routes shows the magnitude of movement in each of these modes. The form of the modal selection model for a service route as was done in this study, can provide the same or different results for each route. This is due to the presence of several influencing factors. Based on the results of research found that the factors group that influence the mode selection of Kupang-Rote are as follows:

$>$ Characteristics of travelers

In this factor group, all variables relate to the individual of the traveler. The variables referred to include factors of gender, age, average monthly income and type of work. Based on the analysis results, several conclusions were drawn regarding the characteristics of ferry transportation, fast ship and aircraft users for both service routes and described as follows:

a. The effect of gender factors on the transportation characteristics users for both service routes describes different conditions. For the KupangRote service route, male travelers generally prefer to use ferries while women prefer to use fast ships.

b. The influence of age factors on the characteristics of transportation users for both service routes illustrates the same conditions. The Kupang-Rote service route describes the characteristics of the travel agent dominated by transportation users in the age range of 20 to 39 years. This is because the age range is a productive age range that travels for work.

c. Most of the travelers who traveled from Kupang were earning less than one million rupiah per month. Most respondents who travel by ferry are respondents with income less than one million rupiah per month. Respondents who earn more than four million rupiah per month prefer to use airplanes, while average respondents that use fast ship earn less than one million rupiah, but the percentage is not as many as the ferry respondents.

d. The traveler from Kupang mostly came from the Civil Servants. Mode transportation that become a choice is a plane because of the comfort factor and travel time factor.

\section{Movement Characteristics}

In this factor group, the existing variables influence travel agents in choosing modes of transportation. The intended variable is a travel intention factor. The characteristics of travelers from Kupang generally travel with the purpose of work and for family purposes. For work purposes, travelers from Kupang prefer to use planes because of the fast travel time and because of convenience. For the family events purpose, travelers from Kupang prefer to use ferries. This is because ferries provide cheap costs especially if done in groups and can allow carrying large quantities of luggage and vehicles.

$>$ Characteristics of transportation mode systems In this factor group, all the variables in question give the influence of travel agents in choosing modes of transportation that are related to the facilities and performance of the transportation system services. These variables are factors of distance and travel time and travel costs. The characteristics of travelers from Kupang generally have to travel more than $10 \mathrm{~km}$ to get to the airport and port. To be able to get to the airport the traveler takes a travel time of less than 20 minutes and 20-40 minutes to get to their destination. To get to the ferry port (Bolok Port), the traveler takes more than 60 minutes to travel. Likewise, to get to the destination the traveler from Kupang who uses a ferry boat takes 40-60 minutes. Similarly, to get to their destination, fast boat users to Rote need 20-40 minutes to their destination.

\subsection{Discussion of the selection model with the users characteristics relationship}

Based on the results of the logit multinomial analysis conducted for the Kupang-Rote route, there are three probability equations model for each service route. Result of the equations and probabilities are as follows:

a. Kapal cepat $=$

$\overline{1+\mathrm{e}^{0,437-1,951 \times 3-1,603 \mathrm{X} 4}+\mathrm{e}^{0,652+2,125 \times 3-2,059 \times 5}}$

Probabilitas pemilihan kapal cepat 34,65 \%

b. $\quad$ Kapal feri $=$

$\mathrm{e}^{0,652+2,125 \times 3-2,059 \times 5}$

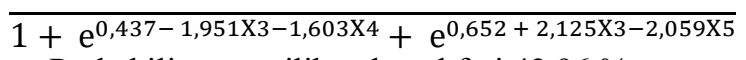

Probabilitas pemilihan kapal feri $42,96 \%$

c. $\quad$ Pesawat $=$

$$
\begin{aligned}
& \frac{1}{1+\mathrm{e}^{0,437-1,951 \mathrm{X} 3-1,603 \mathrm{X} 4}+\mathrm{e}^{0,652+2,125 \mathrm{X} 3-2,059 \mathrm{X} 5}} \\
& \text { Probabilitas pemilihan pesawat } 22,38 \%
\end{aligned}
$$

Where:

$\mathrm{X}_{1}=$ Effect of costs

$\mathrm{X}_{2}=$ Effect of travel time

$\mathrm{X}_{3}=$ factor of luggage

$\mathrm{X}_{4}=$ weather factor

$\mathrm{X}_{5}=$ comfort factor

Judging from the model of equations that are formed, the factors that influence the choice of transportation modes from Kupang are luggage, weather and comfort factors. The luggage factor influences the choice of mode between ferries, fast ship and aircraft because each transportation mode has a different luggage capacity limit for passenger. Luggage capacity on aircraft is limited to each person is $15 \mathrm{~kg}$ while ferries and fast boats do not have luggage capacity limits for each passenger. However, ferries have the advantage of being able to carry vehicles while fast boats are not possible. This causes the luggage factor gives an influence on the mode transportation choice.

The next factors that gives effect to the probability model of mode selection is weather. The weather factor influences the choice of mode because the available 
transportation modes to connect between Rote and Kupang are sea transportation modes and air transportation modes. In certain months such as JanuaryFebruary and June-August, weather influences do not support the use of sea transportation due to high winds and high sea waves. Travelers who travel in these months will generally switch modes from sea transportation to air transportation (aircraft). This also makes travelers think that the comfort level of the aircraft is higher than the other transportation modes.

Based on the influence of luggage, weather and comfort factors on the model of modal selection for Kupang-Rote route, a large probability for each mode of transportation is obtained. The highest probability value for the Kupang-Rote route is on a ferry with a percentage of $42.96 \%$.

\section{Conclusions}

1. Users of transportation services from Kupang in the direction of Rote, in general men prefer to use ferry women prefer to use fast boats. The characteristics of respondents for travel is ages period of 20-39 years. The average user of this service comes from Govermert employee. There are people who travel for work and events for families. When traveling, on average you have to travel more than $10 \mathrm{~km}$ to get to the airport and port.

2. Factors that influence the choice of transportation modes between ferries, fast boats and planes both Kupang-Rote are luggage, weather and comfort. Luggage is the reason for ferries and fast boats to be more dominant. While climate and comfort are the reasons for choosing a plane.Kupang-Rote service route

3. Utility function model of mode selection between fast ships, ferries and aircraft are as follows:

Ufast ship - aircraft $=0,437+0,054 \mathrm{X}_{1}-0,741 \mathrm{X}_{2}$ $1,951 \mathrm{X}_{3}-1,603 \mathrm{X}_{4}+2,197 \mathrm{X}_{5}$

Uferry - aircraft $=0,652+0,129 \mathrm{X}_{1}-1,079 \mathrm{X}_{2}+$ $2,125 \mathrm{X}_{3}+0,575 \mathrm{X}_{4}-2,059 \mathrm{X}_{5}$

Logistic multinomial model:

Fast ship $=$ The probability of fast ship selection is $34.65 \%$

Ferries $=$ The probability of ferry selecting is $42.96 \%$ Plane $=$ The probability of plane selecting is $22.38 \%$

\section{References}

1. H. Abulebu, Studi Pemilihan Moda Untuk Perjalanan Antar Kota Rute Poso-Makasar, Program Pascasarjana Universitas Hasanudin, Makasar (2013)

2. J. Black, Urban Transport Planning, London, Croom Helm (1981)

3. G. Gordon, System Simulation, 2nd edition. Prentice Hall, Englewood Cliffs, New Jersey (1978)

4. F. Miro, Perencanaan Transportasi, Jakarta: Erlangga (2005)

5. Sugiyono, Statistika Untuk Penelitian. Bandung: CV Alfabeta (2007)
6. T.M. Simatupang, Pemodelan Sistem. Nindita: Klaten (1995)

7. R. Simanjuntak, Analisa Pemilihan Moda Transportasi Medan-Rantau Prapat Dengan Menggunakan Metode Stated Preference, Jurusan Teknik Sipil Fakultas Teknik Universitas Sumatera Utara. Medan (2011) 